FisiPublik : Jurnal Ilmu Sosial dan Politik

https://journal.uwgm.ac.id/index.php/fisipublik

P-ISSN: 2528-2689; E-ISSN: 2540-9751

Vol 03 No 02 November 2018,

\title{
Pembangunan Masyarakat Perbatasan di Desa Liang Turan Kecamatan Krayan Barat Kabupaten Nunukan
}

\author{
Eva Veronika ${ }^{1}, \mathrm{Kasim}^{2} \mathrm{Habibi}^{3}$ \\ 123Program Studi Ilmu Administrasi Publik, Fakultas Ilmu Sosial dan Ilmu Politik, Universitas \\ Widya Gama Mahakam Samarinda \\ Email: Evashibon@gmail.com, Muhammadkasim.m@gmail.com, \\ habibimayangmaurai@yahoo.com
}

\begin{abstract}
Abstrak
Tujuan penelitian ini adalah untuk meneliti sejauh mana pembangunan infrastruktur di Desa Liang Turan Kecamatan Krayan Barat Kabupaten Nunukan. Jenis penelitian yang dilakukan adalah deskriftif kualitatif, dengan teknik analisis data menggunakan model interaktif Miles \& Huberman (2011). Hasil penelitian menunjukan bahwa pembangunan infrastruktur di desa Liang Turan kurang baik, hal ini dikarenakan wilayahnya yang terisolasi. Akses jembatan yang menghubungkan antar kecamatan belum semuanya dapat dilalui oleh kendaraan roda 4. Akses jalanpun masih berupa jalan tanah yang apa bila terjadi hujan maka dipastikan kendaraan tidak akan bisa melewati akses jalan tersebut. Barang-barang kebutuhan untuk membangun prasarana kantor desa, gedung sekolah dan rumah ibadah sulit didatangkan, karena satu-satunya akses transportasi yang bisa digunakan adalah melalui transportasi udara dan itupun sangat terbatas. Sedangkan untuk mendatangkan bahan pembangunan dari Malaysia, juga membutuhkan waktu yang lama karena kondisi prasarana Jalan yang tidak baik yang mempengaruhi pembangunan sarana dan prasarana infrastruktur di Desa Liang Turan Kecamatan Krayan Barat Kabupaten Nunukan.
\end{abstract}

Kata Kunci : Pembangunan Infrastruktur, Sarana dan Prasarana, Masyarakat Perbatasan 
FisiPublik : Jurnal Ilmu Sosial dan Politik

https://journal.uwgm.ac.id/index.php/fisipublik

P-ISSN: 2528-2689; E-ISSN: 2540-9751

Vol 03 No 02 November 2018,

Community development the border in Liang Turan Village, Krayan District, Nunukan West Regency

\begin{abstract}
The purpose of this study was to examine the extent of infrastructure development in Liang Turan Village, West Krayan District, Nunukan Regency. This type of research is qualitative descriptive, with data analysis techniques using interactive models of Miles \& Huberman (2011). The results of research showed that infrastructure development in Liang Turan village was not good, this was due to the isolated area. Access to the bridge that connects between sub-districts has not been able to be traversed by four-wheeled vehicles. Even road access is in the form of a dirt road which, if there is rain, it is certain that the vehicle will not be able to pass through the access road. Items needed to build infrastructure for village offices, school buildings and houses of worship are difficult to bring, because the only access to transportation that can be used is through air transportation and that is very limited. Meanwhile, to bring in construction materials from Malaysia, it also takes a long time due to poor road infrastructure conditions that affect the construction of infrastructure facilities and infrastructure in Liang Turan Village, West Krayan District, Nunukan Regency.

Keywords: Development of Infrastructure, Facilities and Infrastructure, Border Communities
\end{abstract}


FisiPublik : Jurnal Ilmu Sosial dan Politik

https://journal.uwgm.ac.id/index.php/fisipublik

P-ISSN: 2528-2689; E-ISSN: 2540-9751

Vol 03 No 02 November 2018,

\section{Pendahuluan}

Wilayah perbatasan merupakan suatu manifestasi bagi kedaulatan wilayah sebuah Negara. Penanganan masalah perbatasan selama ini memang belum dapat diatasi secara optimal dan terpadu, Hal yang lebih memprihatinkan lagi adalah keadaan masyarakat sekitar daerah perbatasan yang seperti lepas dari perhatian Pemerintah. Sebagai contoh adalah wilayah perbatasan di Provinsi Kalimantan Utara Kabupaten Nunukan kecamatan Krayan, yang pembangunan sarana dan prasarana infrastrukturnya jauh dari kata baik jika dibandingkan dengan pembangunan di wilayah perbatasan Negara tetangga Malaysia yang berbatasan langsung dengan wilayah Krayan yaitu Sabah-Sarawak. Perjalanan untuk mencapai kecamatan Krayan dari Kabupaten Nunukan harus ditempuh melalui transportasi udara dengan penerbangan dari bandara Nunukan ke bandara Yufai Semaring, Long Bawan. Kecamatan Krayan merupakan penghasil beras terbesar di Kabupaten Nunukan, yaitu beras adan yang merupakan padi unggul organik, yang banyak dipasarkan ke Malaysia dan Brunei. Daerah ini juga memiliki komoditi unik yaitu garam gunung hasil dari pengolahan sumur air bergaram. Sebagian Wilayah Kecamatan ini berupa Taman Nasional Kayan Mentarang (TNKM) yang kaya akan keanekaragaman hayati. Keaslian alam ini yang berpadu dengan kearifan lokal Suku Dayak dalam mengelola alam yang menjadikan daerah Krayan sering menjadi pusat penelitian sejumlah lembaga nirlaba internasional dan berpotensi besar menjadi daerah tujuan pariwisata.

Hampir semua kondisi infrastruktur jalan yang menghubungkan antar Kecamatan Krayan dengan 65 desa, akses jalannya masih berupa jalan tanah. Sehingga pada saat musim hujan, jalan dengan mudah berubah menjadi becek dan berlumpur dan sulit dilalui baik kendaraan roda dua maupun kendaraan roda empat, sehingga masyarakat kesulitan dalam menjalankan aktivitas, terutama untuk anak-anak bersekolah. Sedangkan pada saat musim kemarau jalan akan menjadi berlubang, dan hal ini juga bisa menjadi penghambat bagi masyarakat dalam melakukan aktivitas.

Satu-satunya akses masyarakat dalam beraktivitas ke Desa lain termasuk ke beberapa Kecamatan yang ada di Krayan dan menuju Bandara Yufai Semaring untuk menuju Ibu Kota Kabupaten Nunukan adalah melalui jalan utama. Artinya jalan utama ini merupakan akses terpenting di Desa, mobilisasi yang menunjang kelancaran kegiatan-kegiatan pembangunan, tetapi juga penunjang kegiatan sosial- kemasyarakatan di Kecamatan Krayan khususnya Di Desa Liang Turan yang disadari letaknya sangat terisolasi. 
FisiPublik : Jurnal Ilmu Sosial dan Politik

https://journal.uwgm.ac.id/index.php/fisipublik

P-ISSN: 2528-2689; E-ISSN: 2540-9751

Vol 03 No 02 November 2018,

Jembatan juga merupakan salah satu akses yang digunakan oleh masyarakat desa untuk menunjang aktivitas, jembatan penghubung antar desa memang sudah ada, akan tetapi masih belum memadai dan masih ada jembatan yang belum bisa dilalui oleh kendaraan roda empat karena kondisi jembatan yang kurang bagus sehingga jembatan hanya bisa digunakan oleh kendaraan roda dua dan juga pejalan kaki. Kebanyakan Jembatan penghubung yang ada di desa Liang Turan adalah jembatan yang masih terbuat dari kayu dan cepat rapuh sehingga tidak terlalu lama digunakan oleh masyarakat. Gedung sekolah, rumah ibadah, Kantor Desa sudah ada, tetapi untuk fasilitas masih kurang. fasilitas untuk gedung sekolah dasar yang digunakan untuk kelas 1-3 masih sangat memprihatinkan kondisinya, karena usia bangunan sekolahnya yang sangat tua sehingga sudah mulai rapuh, bahkan dinding-dindingnya sudah banyak berlubang, begitu juga dengan lantainya yang harus ditambal dengan papan baru untuk menutupi lubang bekas papan yang telah rapuh. Berdasarkan uraian mengenai terbatasnya sarana dan prasarana tersebut diatas dan dipengaruhi oleh beberapa faktor, maka peneliti dalam hal ini terdorong untuk melakukan penelitian dengan judul "Studi Tentang Sarana dan Prasarana Infrastruktur dalam Pembangunan Masyarakat Perbatasan di Desa Liang Turan Kecamatan Krayan Barat Kabupaten Nunukan".

\section{Teori}

Sarana dan prasarana daerah mencakup sarana dan prasarana sosial ekonomi, sosial budaya, transportasi dan perhubungan, telekomunikasi dan informasi, pengairan, dranase, air bersih, air limbah, energi dan lainnya, termasuk tingkat pelayanan pemerintah daerah bidang sarana dan prasarana berikut kebijakan pengembangannya, dan indikator pembangunan daerah bidang prasarana dan sarana daerah (Nurcholis. 2009).

Teguh Widodo mengemukakan bahwa peningkatan sarana dan prasarana meliputi jaringan, jalan, irigasi, jalan, pasar, air bersih, pemanfaatan air limbah dan sampah, mengatakan bahwa peningkatan sarana dan prasarana kesejahteraan sosial meliputi pendidikan, kesehatan, kebudayaan dan sarana prasarana umum lainnya seperti listrik, telekomunikasi dan lain sebagainya (Widodo. 2015)

Peraturan Menteri Desa, Pembangunan Daerah Tertinggal dan Transmigrasi Republik Indonesia Nomor 25 Tahun 2016 Tentang Pembangunan dan Pengembangan Prasarana, Sarana, Dan Utilitas Umum Kawasan Transmigrasi Pasal 1 ayat 15 menyebutkan bahwa Sarana adalah 
FisiPublik : Jurnal Ilmu Sosial dan Politik

https://journal.uwgm.ac.id/index.php/fisipublik

P-ISSN: 2528-2689; E-ISSN: 2540-9751

Vol 03 No 02 November 2018,

fasilitas penunjang, yang berfungsi untuk penyelenggaraan dan pengembangan kehidupan ekonomi, sosial, dan budaya. Peraturan Menteri Desa, Pembangunan Daerah Tertinggal, dan Transmigrasi Republik Indonesia Nomor 25 Tahun 2016 Tentang Pembangunan Dan Pengembangan Prasarana, Sarana, Dan Utilitas Umum Kawasan Transmigrasi Pasal 1 ayat 14 menyatakan bahwa Prasarana adalah kelengkapan dasar fisik kawasan yang memungkinkan lingkungan permukiman dapat berfungsi sebagaimana mestinya.

Prasarana merupakan faktor penunjang berupa gedung sekolah, pengadaan perabot kantor seperti: meja tulis, kursi, lemari penyimpanan, rak buku, atau rak alat keterampilan, filing cabinet, brangkas, pengadaan listrik, air (PAM), telpon, komputer dan lain sebagainya (Suprihatiningsih. 2016). Peraturan Presiden Republik Indonsia Nomor 38 Tahun 2015 pasal 1 ayat 4 Tentang Kerjasama Pemerintah dengan badan usaha dalam penyediaan Infrastruktur mengatakan bahwa Infrastruktur adalah fasilitas teknik, fisik,sistem, perangkat keras dan lunak yang diperlukan untuk melakukan pelayanan kepada masyarakat dan mendukung jaringan struktur agar pertumbuhan ekonomi dan sosial masyarakat dapat berjalan dengan baik.

Infrastruktur fisik dan sosial dapat didefinisikan sebagai kebutuhan dasar fisik pengorganisasian sistem struktur yang diperlukan untuk jaminan ekonomi sektor publik dan sektor prifat sebagai layananan dan fasilitas yang diperlukan agar perekonomian dapat berfungsi dengan baik. Istilah ini merujuk kepada hal infrastruktur teknis atau fisik yang mendukung jaringan struktur seperti fasilitas antara lain dapat berupa jalan, kereta api, air bersih, bandara, kanal, waduk, tanggul, pengelolahan limbah, pelistrikan, telekomunikasi, pelabuhan secara fungsional, infrastruktur selain fasilitasi akan tetapi dapat pula mendukung kelancaran aktivitas ekonomi masyarakat, distribusi aliran, produksi barang dan jasa, sebagai contoh bahwa jalan dapat melancarkan transportasi pengiriman bahan baku sampai kepabrik kemudian untuk distribusi kepasar hingga sampai kepada kemasyarakat. Istilah infrasrtuktur termasuk pula infrastruktur sosial kebutuhan dasar seperti antara lain termasuk sekolah dan rumah sakit (Purba. 2016).

Infrastruktur pekerjaan umum merupakan salah satu infrastruktur vital yang dibutuhkan bagi penunjang kebutuhan masyarakat luas/umum yang terdiri dari tiga bagian utama yaitu:

1. Infrastruktur bina warga: jalan raya, jalan tol dan jembatan,

2. Infrastruktur sumber daya air: waduk, sumber air baku dan instansi pengolahan air baku.

3. Infrastruktur cipta karya (pemukiman): air minum, air bersih (PAM), irigasi, drainase, dan 
FisiPublik : Jurnal Ilmu Sosial dan Politik

https://journal.uwgm.ac.id/index.php/fisipublik

P-ISSN: 2528-2689; E-ISSN: 2540-9751

Vol 03 No 02 November 2018,

sanitasi (persampahan) (Fuad.2015).

Pembangunan sebagai kegiatan-kegiatan yang direncanakan dalam mengolah sumber daya alam dan sumber daya manusia dengan memanfaatkan ilmu pengetahuan dan tekonologi yang digunakan untuk kelangsungan hidup manusia (Santoso. 2016). Proses pembangunan dapat diartikan sebangai upaya yang sistematik dan berkesinambungan untuk menciptakan keadaan yang dapat menyediakan berbagai alternative yang sah, bagi pencapaian aspirasi setiap warga yang paling humanistic. Dengan kata lain, proses pembangunan merupakan proses memanusiakan manusia (Esther 2015).

Pembangunan adalah upaya yang dilakukan secara sadar dan terencana dilaksanakan terusmenerus oleh pemerintah bersama-sama segenap warga masyarakatnya atau dilaksanakan oleh masyarakat dengan dipimpin oleh pemerintah, dengan menggunakan teknologi yang terpilih, untuk memenuhi segala kebutuhan atau memecahkan masalah-maslah yang sedang dan dihadapi, demi tercapainya mutu hidup atau kesejahteraan seluruh warga masyarakat dari suatu bangsa yang merencanakan dan melaksanakan pembangunan tersebut (Mardikato. 2013) Secara sederhana, pembangunan sering diartikan sebagai suatu upaya untuk melakukan perubahan menjadi lebih baik. Karena perubahan yang dimaksud adalah menuju arah peningkatan dari keadaan semula, tidak jarang pula ada yang mengasumsikan bahwa pembangunan adalah juga pertumbuhan.

Masyarakat adalah kelompok manusia yang hidup bersama dan saling bekerja sama untuk kepuasan terhadap berbagai keinginan bersama. Masyarakat merupakan suatu negara apabila cara hidup yang harus ditaati oleh individu dan asosiasi-asosiasi ditentukan oleh suatu kewenangan yang bersifat memaksa dan mengikat (Syahda. 2000). Masyarakat adalah sekelompok orang yang memiliki perasaan sama atau menyatu satu sama lain karena mereka saling berbagi identitas, kepentingan-kepentingan yang sama, perasaan memiliki, dan biasanya satu tempat yang sama. Ada beberapa fungsi masyarakat:

a. Penyedia dan pendistribusi barang-barang dan jasa

b. Lokasi kegiata bisnis dan pekerjaan

c. Keamanan public

d. Organisasi dan partisipasi politik (Edi .2014)

Undang-Undang Republik Indonesia Nomor 6 Tahun 2014 Tentang Desa Pasal ayat (1) Dalam Undang-Undang ini yang dimaksud dengan Desa adalah desa dan desa adat atau yang 
FisiPublik : Jurnal Ilmu Sosial dan Politik

https://journal.uwgm.ac.id/index.php/fisipublik

P-ISSN: 2528-2689; E-ISSN: 2540-9751

Vol 03 No 02 November 2018,

disebut dengan nama lain, selanjutnya disebut Desa, adalah kesatuan masyarakat hukum yang memiliki batas wilayah yang berwenang untuk mengatur dan mengurus urusan pemerintahan, kepentingan masyarakat setempat berdasarkan prakarsa masyarakat, hak asal usul, dan/atau hak tradisional yang diakui dan dihormati dalam sistem pemerintahan Negara Kesatuan Republik Indonesia.

Desa adalah suatu kesatuan masyarakat hukum yang mempunyai susunan asli berdasarkan hak usul yang bersifat istimewa. Landasan pemikiran dalam mengenai pemerintahan desa adalah keanekaragaman, partisipasi, otonomi asli demikratisasi dan pemberdayaan masyarakat (HAW. 2005) Secara historis Desa merupakan cikal bakal terbentuknya masyarakat politik dan pemerintahan diindonesia jauh sebelum negara bangsa ini terbentuk. Struktur sosial sejenis desa, masyarakat adat dan lain sebagainya telah menjadi institusi sosial yang mempunyai posisi yang sangat penting.Desa merupakan institusi yang otonom dengan tradisi, adat istiadat dan hukumnya sendiri serta relatif mandiri. Hal ini Antara lain ditunjukan dengan tingkat keragaman yang tinggi membuat desa mungkin merupakan wujud bangsa yang paling konkret.

\section{Metode}

Penelitian yang digunakan dalam penelitian ini adalah penelitian deskriptif kualitatif, penelitian kualitatif bermaksud membuat penggambaran secara sistematis, faktual, dan akurat mengenai fakta-fakta dan sifat-sifat populasi tertentu (Usman. 2004). Dengan kata lain penelitian ini bertujuan untuk menggambarkan sifat sesuatu yang tengah berlangsung pada saat studi. Pengumpulan data dilakukan dengan penelitian kepustakaan dan penelitian lapangan (observasi, dokumentasi, wawancara). Penelitian dilakukan di Desa Liang Turan Kecamatan Krayan Barat Kabupaten Nunukan. Pemilihan informan dengan metode purposive Sampling dengan Kepala Desa Liang Turan sebagai key informan. Analisa data meliputi empat komponen yaitu: Pengumpulan Data, Reduksi Data, Penyajian Data dan Pengambilan Kesimpulan. Definisi Konsepsional merupakan tahapan dalam memberikan batasan mengenai suatu istilah yang diperlukan dalam penelitian ini, pembatasan pengertian tersebut akan mempermudah penulis dalam memahami dan juga menghindari adanya sebuah penulisan dari apa yang diinginkan serta untuk mengatasi lingkup penulis. Didasari oleh uraian diatas maka definisi konsepsional dari 
FisiPublik : Jurnal Ilmu Sosial dan Politik

https://journal.uwgm.ac.id/index.php/fisipublik

P-ISSN: 2528-2689; E-ISSN: 2540-9751

Vol 03 No 02 November 2018,

penelitian ini, yang dimaksud dengan Sarana Dan Prasarana Infrastruktur Dalam Pembangunan Masyarakat Perbatasan di Desa Liang Turan Kecamatan Krayan Barat Kabupaten Nunukan adalah Pembangunan yang dilaksanakan oleh pemerintah yang pada umumnya bersifat sarana dan prasarana infrastruktur, seperti pembangunan jalan, jembatan penghubung, gedung-gedung, seperti gedung sekolah, kantor desa dan rumah ibadah serta kegiatan-kegiatan lain dibidang ekonomi, sosial budaya, prasarana Balai Desa, Dalam penelitian ini, peneliti meneliti tentang pembangunan sarana dan Prasarana Infrastruktur Dalam Meningkatkan Kesejahteraaan Masyarakat dengan beberapa fokus penelitian. Hal ini disebabkan keterbatasan waktu dan biaya yang peneliti miliki. Sehingga yang menjadi fokus dalam penelitian ini adalah:

1. Sarana Infrastruktur meliputi:
a. Sarana Sekolah Dasar
b. Sarana Rumah Ibadah
c. Sarana Kantor Desa

2. Prasarana infrastruktur meliputi:
a. Gedung Sekolah Dasar
b. Rumah Ibadah.
c. Kantor Desa
d. Jalan dan Jembatan penghubung

\section{Pembahasan}

\section{Kondisi Sarana Infrastruktur}

\section{Sekolah}

Sarana yang dimiliki sekolah masih kurang dan belum memadai. Seperti tenaga pengajar yang sedikit dan tidak seimbang dengan banyaknya murid, dimana jumlah tenaga pengajar hanya sepuluh orang termasuk Kepala Sekolah dengan tenaga Honor berjumlah enam orang dan Aparatur Sipil Negara (ASN) sebanyak empat orang. Untuk kelengkapan di dalam kelas, tidak adanya rak buku di dalam kelas dan kelengkapan olahraga juga masih kurang.

2. Rumah Ibadah

Sarana dalam rumah Ibadah yang masih banyak yang belum lengkap, saat ini hanya alat musik 
FisiPublik : Jurnal Ilmu Sosial dan Politik

https://journal.uwgm.ac.id/index.php/fisipublik

P-ISSN: 2528-2689; E-ISSN: 2540-9751

Vol 03 No 02 November 2018,

standar yang kita gunakan, untuk sementara kursi-kursi yang ada sudah cukup hanya untuk Jemaat yang ada, tetapi jelas akan kurang ketika ada ibadah gabungan dikarenakan saat ibadah gabungan dilaksanakan masih ada beberapa jemaat gereja yang berdiri.

\section{Kantor Desa}

Sarana dalam Kantor Desa belum lengkap, hal ini bisa kita lihat dari meja dan kursi yang masih kurang, rak buku, serta masih banyak fasilitas-fasilitas Kantor Desa lain yang tidak ada. Hal ini menyebabkan perangkat desa harus bekerja di rumah masing-masing dan saat ada pertemuan rapat harus dilakukan di rumah-rumah atau menyesuaikan situasi dan kondisinya.

\section{Kondisi Prasarana Infrastruktur}

\section{Sekolah}

Prasarana sekolah sudah ada tetapi masih kurang baik. Bangunan yang pertama bersifat semi permanen dan berjumlah tiga kelas serta satu ruang guru, sedangkan satu bangunan lagi merupakan bangunan lama yang terbuat dari kayu tetapi usia bangunan tersebut sudah sangat tua.

\section{Rumah Ibadah}

Pembangunan gedung gereja sudah baik tetapi masih kurang besar, hal ini menyebabkan jemaat yang setiap tahun selalu bertambah terus serta sering dilakukannya ibadah gabungan membuat ruang ibadah tidak muat.

\section{Kantor Desa}

Prasarana untuk Kantor desa Liang Turan sudah baik tetapi masih dalam tahap pembangunan. Pembangunan Kantor desa ini sudah terbuat dari Beton dengan menggunakan Dana Desa yang di berikan oleh pemerintah. Meskipun pembangunan Kantor Desa belum sepenuhnya selesai namun sudah bisa digunakan. Pembangunan selanjutnya masih belum bisa dilaksanakan dikarenakan bahan material bangunan yang belum ada.

4. Jalan dan Jembatan Penghubung

Kondisi jalan dan jembatan yang ada saat ini bisa dikatakan sangat memprihatinkan, kondisi jalan yang sudah sangat rusak dan tidak bisa dilalui oleh kendaraan roda 4 dan roda 2 pada saat musim hujan. Sama halnya dengan jembatan yang terbuat dari kayu, sudah baik tetapi tidak bisa bertahan lama, karenasering dilalui oleh masyarakat desa baik pejalan kaki maupun yang 
FisiPublik : Jurnal Ilmu Sosial dan Politik

https://journal.uwgm.ac.id/index.php/fisipublik

P-ISSN: 2528-2689; E-ISSN: 2540-9751

Vol 03 No 02 November 2018,

memiliki kendaraan.

\section{Faktor Pendukung dan Penghambat Pembangunan Sarana dan prasarana Infrastruktur}

Adanya upaya dari pemerintah untuk meningkatkan maupun merencanakan program untuk pembangunan, serta SDA yang mendukung dalam pembangunan. Wilayah krayan yang masih termasuk daam wilayah yang terisolasi, sehingga untuk mendatangkan sarana kelengkapan sekolah cukup sulit karena hanya transportasi udara yang bisa digunakan hingga saat ini. Adanya kerjasama yang baik dari Jemaat Gereja serta masyarakat yang ikut berpartisipasi dalam pembangunan, baik dukungan berupa sumbangan mater dan non materi untuk sarana maupun untuk prasarana dalam Rumah Ibadah. Mendatangkan alat dan bahan material untuk pembangunan sangat sulit dilakukan karena wilayah krayan yang masih terisolasi.

\section{Kesimpulan}

Berdasarkan penyajian data dan pembahasan yang telah diuraikan pada bab-bab sebelumnya, maka peneliti dapat menarik kesimpulan mengenai Sarana dan Prasaran Infrastruktur dalam Pembangunan Masyarakat Perbatasan di Desa Liang Turan sebagai Berikut: Ditinjau dari pembangunan sarana infrastruktur sekolah dasar seperti tenaga pengajar yang masih kurang dan kelengkapan peralatan pendidikan juga masih kurang. Sarana rumah ibadah seperti hanya peralatan musik standar yang digunakan serta sarana Kantor desa yang masih belum lengkap dan perlu ditingkatkan lagi. Ditinjau dari pembangunan prasarana infrastruktur sekolah dasar yang perlu ditingkatkan lagi karena saat ini masih digunakan gedung sekolah yang sudah lama dimana dinding dan lantainya nya sudah berlubang. Prsarana rumah ibadah sudah bagus hanya saja perlu diperlebarkan lagi sedangkan prasarana Kantor desa sudah bagus degan pembangunan yang memadai serta jalan dan jembatan perlu ditingkatkan lagi karena setelah diperbaiki akan dapat mendukung dan penunjang terselenggaranya suatu proses pembangunan. Faktor-faktor Penghambat pembangunan sarana dan prasarana infrastruktur di Desa Liang Turan yaitu karena wilayahnya yang terisolasi. Barang-barang kebutuhan untuk membangun prasarana Kantor desa, gedung sekolah dan rumah ibadah sulit didatangkan, karena satu- satunya akses transportasi yang bisa digunakan adalah melalui transportasi udara dan itupun sangat terbatas. Sedangkan untuk mendatangkan bahan pembangunan dari Malaysia, juga membutuhkan waktu yang lama karena 
FisiPublik : Jurnal Ilmu Sosial dan Politik

https://journal.uwgm.ac.id/index.php/fisipublik

P-ISSN: 2528-2689; E-ISSN: 2540-9751

Vol 03 No 02 November 2018,

kondisi prasarana Jalan yang tidak baik juga mempengaruhi pembangunan sarana dan prasarana infrastruktur di Desa Liang Turan. Faktor pendukung dalam pembangunan sarana dan prasarana infrastruktur yaitu adanya upaya pemerintah Desa melalui program-program pemerintah yang akan dilaksanakan maupun menindak lanjuti program yang sudah berjalan dan masyarakat juga ikut berpartisipasi dan mendukung dalam prmbangunan. Semua ini untuk mengatasi permasalahan-permasalahan yang ada pada setiap bidang-bidangnya.

\section{Daftar Pustaka}

Anonim, Peraturan Menteri Desa, Pembangunan Daerah Tertinggal, Dan Transmigrasi Republik Indonesia Nomor 25 Tahun 2016 Tentang Pembangunan Dan Pengembangan Prasarana, Sarana, Dan Utilitas Umum Kawasan Transmigrasi.

Peraturan Presiden Nomor 2 Tahun 2015, Tentang Rencana Pembangunan Jangka Menengah Nasional Tahun 2015-2019.

Peraturan Presiden Republik Indonesia Nomor 38 Tahun 2015

Tentang

Kerjasama Pemerintah Dengan Badan Usaha Dalam Penyediaan Infrastruktur.

Undang-Undang Nomor 23 Tahun 2014, Tentang Pemerintah Daerah.

Undang-Undang Dasar Negara Republik Indonesia Tahun 1945

Undang-Undang Republik Indonesia Nomor 11 Tahun 2009 Tentang Kesejahteraan Sosial.

Darwin Purba, 2016, Menuju Indonesia Baru Jilid 1, Penerbit Guepedia, Jakarta.

Edi Suharto, 2014, Membangun Masyarakat Memberdayakan Rakyat (Kajian Strategis

Pembangunan Kesejahteraan Sosial Dan Pekerjaan Sosial), Penerbit Pt. Refika Aditama, Bandung.

Ester Kembauw, Lexy J. Sinau Dan Aphrodite M. Sahuwilane, 2015, Pembangunan Perekonomian Maluku, Penerbit Deeplubish, Yogyakarta.

Hanif Nurcholis, 2009, Perencanaan Partisipatif Daerah, Penerbit Grasindo, Jakarta. Haw Widjaja, 2005, Otonomi Desa, Penerbit Pt Rajagrafindo Persada, Jakarta.

Sugiyono, 2011, Metodologi Penelitian Kuantitatif Dan R\&D, Penerbit Alfabeta, Bandung. 2009, Metode Penelitian Pendidikan, Penertbit Alfabeta, Bandung.

Suprihatiningsih, 2016, Perspektif Manajemen Pembelajaran Program Keterampilan, Penerbit Deeplubish, Yogyakarta. 
FisiPublik : Jurnal Ilmu Sosial dan Politik

https://journal.uwgm.ac.id/index.php/fisipublik

P-ISSN: 2528-2689; E-ISSN: 2540-9751

Vol 03 No 02 November 2018,

Syahda Guruh Langkah Samudra, 2000, Menimbang Otonomi Vs Federal (Mengembangkan Wacana Federalismedan Otonomi Luas Menuju Masyarakat Madani Indonesia), Penerbit Pt Remaja Rosdakarya, Bandung.

Teguh Widodo, 2015, Pembangunan Endogen: Mengabaikan Peran Negara Dalam Pembangunan,

Penerbit Deeplubish, Yogyakarta

Usman Husaini Dan Akbar Purnomo Settiady, 2004, Metodologi Penelitian Sosial, Penerbit Bumi Aksara, Jakarta.

Zainul Fuad, Entatarina Simanjuntak Dan Hasna Widyaastuti, 2015, Strategi Pendayagunaan Badan Usaha Milik Pemerintah (Bumn Dan Bumd) Dalam Pembiayaan Infrastruktur Pekerjaan Umum 2014, Penerbit Pusat Kajian Strategis Pekerjaan, Umum 2015, Jakarta

Http://Jurnal.Unimed.Ac.Id/2012/Index.Php/Geo 2017/12/04;08.36 Pm 